\title{
Kigiryama Phonology
}

\author{
Dr. Elizabeth Jumwa Munyaya \\ Pwani University, Kilifi, Kenya
}

\begin{abstract}
This paper provides an in-depth introduction to the Phonology of Kigiryama language. Phonetics is the study of how the sounds of the world's languages are produced and perceived. Phonology is the study of how these sounds are categorized, contrasted, and organized into larger structures in each language. In this paper, we will begin with a description of the phonotactics of Kigiryama language and Kigiryama syllable structure. Finally, this paper will analyze the phonological processes involved with both vowels and consonants in the language in question. The aim of the study is to give a phonological description of Kigiryama vowels and consonants with a special reference to the phonological processes that occur in these phonemes. Data will be collected through interview schedules and focus group discussions. Analysis of the data will involve first translating the data into English, then classifying and describing the words into the phonological processes of the vowels and consonants. The findings will show that the processes of glide formation, vowel deletion, vowel insertion and vowel height assimilation occur mainly with vowels while the processes of palatalization, labialization and assibilation occur mainly with consonants. Throughout the paper, we will work with real data from a diverse sample of the Kigiryama language. This information is fundamental to any linguistic study since it forms a foundation upon which various levels of linguistic analysis of Kigiyama is based.
\end{abstract}

Key Words: Phonotactics, Syllabicity, Labialization, Palatalization, Vowel Height Assimilation, Vowel Deletion And Insertion, Assibilation And Glide Formation.

\section{INTRODUCTION}

$\mathrm{T}$ his paper deals with Kigiryama phonological system. We will focus mainly on segmental features; such as the vowels and consonants in the language in question and prosodic elements which include; stress, tone and intonation.

It is important to make a distinction between the two concepts; phonetics is the science that studies sounds; how sounds are produced in general while phonology is the study of the sound system of a particular language. Phonology also includes stress, rhythm and intonation. This paper will therefore be based on phonology rather than phonetics

Phonology is important when teaching or learning a language for the following reasons. Firstly, the problem with vowels is that students need to be able to perceive, distinguish and pronounce correctly a number of vowels that exist, if they don't their communication skills will suffer especially with regards to listening and speaking because they will confuse such words such as;

$$
\begin{aligned}
& \text { / Kala/......... a piece of charcoal } \\
& \text { /kala/.......... a jackal }
\end{aligned}
$$

Identifying the individual sounds of Kigiryama is a great skill and involves a lot of practice. Conveying or presenting those sounds in writing is a further skill which involves learning the IPA Alphabet.

Another reason in favor of phonological training in the classroom is that there is some pattern of relationship between the Kigiryama spellings and pronunciation.

Thirdly, and perhaps the most important reason for phonetic training in the class is that 'bad habits die hard'. if a child internalizes an inaccurate or bad pronunciation of Kigiryama, this pronunciation will be difficult to improve in the future.

An important purpose of the paper is to explain how Kigiryama is pronounced in the accent normally chosen as the standard for people learning the Kigiryama spoken in the Giryama speaking areas.

This paper is aimed at, presenting information in the context of a general theory about speech sounds and how they are used in the Kigiryama language.

The theoretical material in the present paper is necessary for anyone who needs to understand the principles regulating the use of sounds in spoken Kigiryama.

\section{Objectives:}

This paper aims at tackling the following objectives

a. Describe the phonotactics and syllable structure of the Kigiryama language.

b. Analyze the phonological processes involved with both vowels and consonants of Kigiryama language.

Just like other languages Kigiryama speech is composed of sound segments that are consonants or vowels. This natural classification has been used in many languages of the world and is based on the degree of obstruction of the airstreams (Abercrombie 1966, Ladefoged 1982 and 1971).

Apart from the segmental features, Kigiryama has supra segmental features. These two aspects of Phonology of Kigiryama can be distinguished clearly.

According to Ladefoged(1975), the supra segmental features are those aspects of speech that involve more than single consonants and vowels. These features are often superimposed on the syllable. Kigiryama has supra-segmental features of stress, tone and pitch.

These features are independent of the features and categories phonemes, however, we will concern ourselves with segmental features of the Kigiryama phonology in particular we aim to describe the phono tactics in Kigiryama as well as 
analyze the phonological processes involved with vowels and consonants in the language. Phono tactics of a language deal with the sequence of segments in that language. Consonant cluster is a sequence which:-

a. Does not have a morpheme boundary and

b. Must not have undergone any morphological alteration. For example the English language permits a three consonant cluster

\section{METHODOLOGY}

\subsection{Research design}

The nature of the research prompted the adoption of a descriptive research design and research questions and interviews as the data collection methods. The descriptive research design allowed the researcher to obtain information without changing the environment more so, the language was not manipulated in any way. Such a design, enabled the researcher obtain information about the naturally occurring processes in Kigiryama language. Similarly, the descriptive design was chosen since the study involved a one-time interaction with the Giryama speakers in the form of interviews in order to collect and analyze the various processes in Kigiryama.

\subsection{Location of Study}

The research was carried out in Kilifi County, Kenya. Purposive sampling was used to select Kilifi County as the study and most specifically Bamba township and Galana in Magarini divisions' since they have the largest number of settlement schemes occupied by Giryama speakers and again in Bamba and Galana divisions is where we have most of the Giryama native speakers residing.

\subsection{Population of the study}

The study mainly targeted the educated Giryama speakers in Bamba and Galana divisions since the speakers in these areas are accessible. In Bamba, not the whole Giryama region was targeted but only the speakers in Bamba town while in Galana, the researcher concentrated on the speakers in Mjanaheri because it is the area where the researcher comes from. The words collected were mainly nouns, verbs and adjectives.

\section{$2.4 \quad$ Sample and sampling techniques}

Purposive sampling was used to select the 5 language experts because the language spoken by these people has not been corrupted by issues sheng, code mixing or switching in the areas where they comefrom.Purposive sampling technique was also used to select the people that were to be studied, based on the judgement of the researcher. The researcher's goal was not only to randomly select the respondents from a population but also to create a sample with the intention of making generalizations from the sample to the population of interest.
The researcher's main goal on using purposive sampling was to focus on particular characteristics of the Giryama people that are of interest and which will best enable her to answer the research questions.

\subsection{Research Instruments}

Data which consisted ofKigiryama sounds and words were collected using questionnaires. The questionnaires were administered to those who could read and write. For those respondents who could not read and write, interviews were conducted and they involved prompting to elicit the various words with sounds in Kigiryama. The questionnaire was developed by the researcher.

Library research was also conducted to collect the various phonological processes of involving both vowels and consonants.

\subsection{Data collection methods}

Data collection was carried out in this study beginning with library search exploring Kigiryama written materials such as the Kigiryama bible and TujifunzeKuongeaKikwetu (TKK) series of children's books. This was then followed by interviews and questionnaires. The questionnaires and interviews, however, involved prompting. The primary source of data for this work was words based on a questionnaire devised by the researcher to elicit the words showing the various sounds and the phono tactics in the language. The questionnaire was also used to obtain examples of words that illustrate the various phonological processes in the language (primarily in Kigiryama).

\subsection{Data Analysis and procedures}

After administration, the questionnaires and structured interview schedules were then collected; data was then appropriately organized into themes categories and objectives relevant to the study. The results were presented in tables on the basis of the research objectives. Analysis and interpretation was done to determine clear characteristics and relationships that exist between the variables.

\section{RESEARCH FINDINGS}

This chapter discusses the various aspects of Phonology in Kigiryama language. The section begins begins by giving a description of the phono tactics of both the vowels and consonants in Kigiryama, it then goes further to identify the consonant clustersthat occur in Kigiryama and the section goes further to explain the Kigiryama syllable structure and finally ends with an explanation of thephonological processes affecting Kigiryamavowels and consonants in Kigiryama words.

\subsection{Phono tactics of Kigiryama Vowels}

Phono tactics as earlier mentioned deal with the sequence of segments in a language. Sequence of segments are not random but are ordered. Kigiryama has a V1V1 sequence, meaning that two similar segments can occur in a sequence. For 
instance check the examples of two vowel sequences of words in the Kigiryama language.

Table 1: Examples of Words in Kigiryama with two vowel sequence

\begin{tabular}{|c|c|c|c|}
\hline $\begin{array}{c}\text { Vowel } \\
\text { sequence }\end{array}$ & Word & Transcription & Gloss \\
\hline /ii/ & $\begin{array}{l}\text { Bidhii } \\
\text { Tibii } \\
\text { Kavii } \\
\text { Vivii } \\
\text { ii }\end{array}$ & $\begin{array}{l}\text { /Biðii/ } \\
\text { /tibii/ } \\
\text { /kavii/ } \\
\text { /vivii// } \\
\text { /ii// }\end{array}$ & $\begin{array}{c}\text { 'determination' } \\
\text { 'tuberculosis' } \\
\text { 'dikdik' } \\
\text { 'very bad' } \\
\text { 'this' }\end{array}$ \\
\hline /ee/ & $\begin{array}{l}\text { Mwee } \\
\text { Siyee } \\
\text { wee }\end{array}$ & $\begin{array}{l}\text { /mwee/ } \\
\text { /sijee/ } \\
\text { /wee/ }\end{array}$ & $\begin{array}{l}\text { 'eagle' } \\
\text { 'there he is' } \\
\text { 'you' }\end{array}$ \\
\hline /oo/ & $\begin{array}{l}\text { Poo } \\
\text { Choo } \\
\text { koo } \\
\text { Ndoo } \\
\text { voo }\end{array}$ & $\begin{array}{l}\text { /poo/ } \\
\text { //t5oo/ } \\
\text { /koo/ } \\
\text { /ndoo/ } \\
\text { /voo/ }\end{array}$ & $\begin{array}{l}\text { 'here he comes' } \\
\text { 'toilet' } \\
\text { 'throat' } \\
\text { 'bucket' } \\
\text { 'expression of } \\
\text { watery thing } \\
\text { pouring' }\end{array}$ \\
\hline /uu/ & $\begin{array}{c}\text { Vuu } \\
\text { Kuuya } \\
\text { Kuukuu } \\
\text { Puu }\end{array}$ & $\begin{array}{l}\text { /vuu/ } \\
\text { /kuuja/ } \\
\text { /kuukuu/ } \\
\text { /puu/ }\end{array}$ & $\begin{array}{l}\text { 'hippopotamus' } \\
\text { 'to come back' } \\
\text { 'old (of a dress) } \\
\text { Expression of a } \\
\text { bad smell }\end{array}$ \\
\hline aa & $\begin{array}{l}\text { Aa } \\
\text { Maazo } \\
\text { kulaa }\end{array}$ & $\begin{array}{c}\text { /aa/ } \\
\text { /maazo/ } \\
\text { /kulaa/ }\end{array}$ & $\begin{array}{l}\text { 'these people' } \\
\text { 'thoughts' } \\
\text { 'gone away' }\end{array}$ \\
\hline
\end{tabular}

Similarly Kigiryama has V1V2 vowel sequence meaning that two different vowel segments can occur in a sequence in a word.

Check the illustrated examples below;

\begin{tabular}{|c|c|c|c|}
\hline V1V2 sequence & Kigiryama word & transcription & gloss \\
\hline $\begin{array}{l}\text { ie } \\
\text { io }\end{array}$ & $\begin{array}{c}\text { Andzie } \\
\text { Akiona } \\
\text { Akioya } \\
\text { madziohenda }\end{array}$ & $\begin{array}{c}\text { /andzie/ } \\
\text { /akiona/ } \\
\text { /akioja/ } \\
\text { /madziohenda/ }\end{array}$ & $\begin{array}{c}\text { 'his friends' } \\
\text { 'he saw' } \\
\text { 'he rested' } \\
\text { 'who have done' }\end{array}$ \\
\hline iu & akiuka & /akiuka/ & 'when he left' \\
\hline ia & $\begin{array}{c}\text { Via } \\
\text { Dhia } \\
\text { Gunia } \\
\text { Muthumia } \\
\text { akiamba }\end{array}$ & 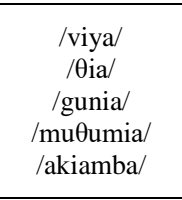 & $\begin{array}{c}\text { 'utensils' } \\
\text { 'to wish for bad } \\
\text { luck' } \\
\text { 'sack' } \\
\text { 'an old man' } \\
\text { 'he said' }\end{array}$ \\
\hline ai & $\begin{array}{c}\text { Bai } \\
\text { Utsai } \\
\text { Maini } \\
\text { kanaiza }\end{array}$ & $\begin{array}{l}\text { /bai/ } \\
\text { /utsai/ } \\
\text { /maini/ } \\
\text { /kanaiza/ }\end{array}$ & $\begin{array}{l}\text { 'therefore' } \\
\text { 'witchcraft' } \\
\text { Liver' } \\
\text { 'refute }\end{array}$ \\
\hline ao & $\begin{array}{c}\text { Ao } \\
\text { Kwao } \\
\text { Chao } \\
\text { Ugwirao } \\
\text { naona }\end{array}$ & $\begin{array}{c}\text { /ao/ } \\
\text { /kwao/ } \\
\text { /tfao/ } \\
\text { /ugwirao/ } \\
\text { /naona/ }\end{array}$ & $\begin{array}{l}\text { 'them' } \\
\text { 'at their place' } \\
\text { 'their thing', } \\
\text { 'that catches' } \\
\text { 'I am seeing' }\end{array}$ \\
\hline $\mathrm{au}$ & $\begin{array}{l}\text { Dau } \\
\text { Shauri } \\
\text { Chausa } \\
\text { Laula } \\
\text { rauka } \\
\end{array}$ & $\begin{array}{l}\text { /dau/ } \\
\text { / Sauri/ } \\
\text { /t fausa/ } \\
\text { /laula/ } \\
\text { /rauka/ }\end{array}$ & $\begin{array}{l}\text { 'boat' } \\
\text { 'opinion' } \\
\text { 'reason' } \\
\text { 'to inspect' } \\
\text { 'come early' }\end{array}$ \\
\hline ea & tsea & /tsea/ & 'to joke' \\
\hline ua & kuamba & /kuamba/ & 'to say' \\
\hline ui & kuiha & /kuiha/ & 'to call' \\
\hline
\end{tabular}

\begin{tabular}{|c|l|l|c|}
\hline ui & kuiya & $/ \mathrm{kuija} /$ & 'to steal' \\
\hline uo & kuola & $/ \mathrm{kuola} /$ & 'to rot' \\
\hline
\end{tabular}

The above examples illustrate the two vowel cluster in Kigiryama, however, there are no three vowel cluster in the language.

\subsection{Phono tactics of Kigiryama Consonants}

Phono tactics deal with the sequence of segments in any language. In Kigiryama, consonant cluster is a sequence of consonants which have the following properties;

1. Does not have a morpheme boundary

2. Must not have undergone any morphological alteration.

3. Must not be a glide i.e a w or $y$.

We need to know the consonant cluster of a given language in this case Kigiryama, in order to be able to pronounce the sounds correctly. The following are some of the consonant clusters that occur in Kigiryama:

1. Syllabicity

2. Nasal Compounds.

We will discuss and explain each of the mentioned consonant clusters in detail.

\section{Syllabicity}

Syllabicity refers to a process by which a consonant becomes syllabic. A syllabic consonant is identified or indicated by an exceptional syllable where certain consonants occur alone to form the syllable. The nasals and laterals are good examples according to Crystal, (1997:375). Consider the following examples in Kigiryama.

\begin{tabular}{|c|c|c|}
\hline Kigiryama word & Transcription & Gloss \\
\hline mfadzi & $\underline{\mathrm{m}+\mathrm{fadzi}}$ & 'the late' \\
\hline ndzovu & $\underline{\mathrm{n}}+\mathrm{dzovu}$ & 'an elephant' \\
\hline nguwo & $\underline{\mathrm{n}}+$ guwo & 'a dress' \\
\hline ndzugu & $\underline{\mathrm{n}+\mathrm{dzugu}}$ & 'groundnuts' \\
\hline mbuzi & $\underline{\mathrm{m}+\text { buzi }}$ & 'a goat' \\
\hline ngombe & $\underline{n}$ gombe & 'a cow' \\
\hline nyonga & nonga & 'a waist' \\
\hline
\end{tabular}

From the above examples, $\mathbf{m}, \mathbf{n}$ and $\mathbf{n}$ acquire syllabicity at word initial position. This means that the when these sounds appear at the initial position in a word they become syllabic and hence referred to as syllabic consonants. They are pronounced with stress and emphasis.

\section{Nasal Compounds}

Apart from the syllabic consonants, Kigiryama also has nasal compounds. Kigiryama nasal compounds are six in number and include; [mb], [nd], [ndz], [nz], [n] spelled as [ny ], and [y] spelled as ng]. These nasal compounds are basically homorganic co articulations whereby the first consonant is a 
nasal and the second is a non-nasal consonant but articulated at the same place of articulation as the nasal. Schane (1973:210) posits that a nasal compound is a consonant proceeded by nasal and is realized as a phoneme unit.

In Kigiryama, the nasal compounds occur in basic word forms and in any syllable position i.e in word initial, medial and even in word final position. The table below illustrates this.

\begin{tabular}{|c|c|c|}
\hline $\begin{array}{c}\text { Nasal } \\
\text { compound }\end{array}$ & Kigiryama word & Gloss \\
\hline $\mathrm{mb}$ & $\begin{array}{c}\text { Mbadha } \\
\text { Hambala } \\
\text { kumba }\end{array}$ & $\begin{array}{c}\text { 'agreed date' } \\
\text { 'to crawl' (of an insect) } \\
\text { 'fresh water fish' }\end{array}$ \\
\hline $\mathrm{nd}$ & $\begin{array}{c}\text { Handika } \\
\text { honda }\end{array}$ & $\begin{array}{c}\text { 'a bat' } \\
\text { 'to make a bed' } \\
\text { 'to pound' }\end{array}$ \\
\hline $\mathrm{ndz}$ & $\begin{array}{c}\text { Ndzugu } \\
\text { andzandza } \\
\text { Kuhendza }\end{array}$ & $\begin{array}{c}\text { 'groundnuts' } \\
\text { 'to economize' } \\
\text { 'to like/love' }\end{array}$ \\
\hline $\mathrm{nz}$ & $\begin{array}{c}\text { Nzala } \\
\text { honze }\end{array}$ & $\begin{array}{c}\text { 'nzala' } \\
\text { 'outside' }\end{array}$ \\
\hline $\mathrm{nj}$ & $\begin{array}{c}\text { Njama } \\
\text { honje }\end{array}$ & $\begin{array}{c}\text { 'a secret' } \\
\text { 'dough of ugali' }\end{array}$ \\
\hline $\mathrm{ng}$ & $\begin{array}{c}\text { Ngombe } \\
\text { Hunguza } \\
\text { kenga }\end{array}$ & $\begin{array}{c}\text { 'a cow' } \\
\text { 'to reduce' } \\
\text { 'to cheat' }\end{array}$ \\
\hline
\end{tabular}

\subsection{Kigiryama syllable structure}

Just like in many African languages, Kigiryamasyllubles are made up of two segments: a consonant and a vowel. There are however, few cases of nasal compounds where two segments (which appear as two consonants) and a vowel make up a syllable. These syllables function as single units segments in the language and are therefore considered as one consonantal segment. (seeSchane, 1973:210).

The open syllable structure, a consonant-vowel sequence $(\mathrm{CV})$ is the most preferred structure in Kigiryama. This is because the syllable is not 'closed' by another consonant hence called open syllable type. Kumbatha (1998:24) says there is no closed syllable in forms with derivational or inflectional morphes in Kigiryama. Closed syllables occur in roots of word forms.

Apart from the roots of words, all syllables in Kigiryama end in a vowel. No syllable of stems and word forms end in consonant. In Kigiryama, certain consonant and vowel processes take place at morpheme boundaries.

These phonological processes, which alter the original syllable structure in a word, take place at syllable boundary. Examples of such processes in Kigiryama are glide formation and vowel deletion. The motivation for these processes is toward the preferred syllable structure of the language. Such processes come into play to alter a syllable structure to the preferred syllable structure of CV alteration. In Kigiryama, all the natural rules for preferred syllable structure must yield the optimal structure with consonant-vowel alteration. The Kigiryama syllable structure is more tolerant to consonants clusters than to vowel clusters. It is usually the case that vowels are deleted, coalesced or changed to glides whenever they cluster. This yields the optimal CV alteration structure and also explains why consonant cluster forms such as [nd], [ng], [mb], [nz], [ts], [dz], [nj], [zh] and [ndz] are prevalent in Kigiryama. (Kumbatha,1998:25).

\subsection{Phonological Processes involving Vowels.}

According to Bauer (2003:60) there are many phonological processes in the languages of the world whose application is determined by the boundaries of units larger than the segment. Some can apply at the end of a syllable or at the beginning of a morpheme. The application of these processes is influenced by a unit which we can identify as a word form. These processes thus provide an extra way of determining where the boundary of the word form falls. In Kigiryama the following vowel processes; glide formation, vowel deletion and vowel insertion occur.

\subsubsection{Glide Formation}

Glide formation is a synchronic vowel process that changes vowels into semivowels which are referred to as glides. Glides are consonants which have vowel like articulation features and are produced with the body of the tongue raised to take the position for production of high vowels in the mouth with the tongue closer to the palate.

In Kigiryama the palatal glide $/ \mathrm{j}$ / corresponds to the high front vowel /i/ whereas the bilabial glide /w/ corresponds to the high back vowel /u/. Abdulmajid (2000), states that Glide formation processes take two forms; namely:-

i. Glides formed on the stem.

ii. Glides formed on the root.

\section{Glide formed on the stem}

In Kigiryama this kind of glide formation occurs at the boundary of the prefix and the root. Glides formed on the root in the environment where the prefix has the high-back vowel /u/ followed by the front vowels /i/, /e/, or /a/ or an identical vowel /o/. Accrding to Abdulmajid,(2000) such a form of glide formation reqires that 'the noun root vowel as well as the prefix vowel assimilate to give rise to the glide /w/ which is bilabial without any change in the meaning of the word.

In Kigiryama the glide formation for $/ \mathrm{w} /$ is prominent in the class prefix $/ \mathrm{mu} /$ for the formation of doer nouns. The $/ \mathrm{u} / \mathrm{in}$ the noun class prefix changes to a glide when it precedes a vowel especially if the morpheme $/ \mathrm{mu} /$ is added to a root of a word that begins with a vowel.

The rule can be stated as follows; the vowel /u/ changes to /w/ in the environment preceding a vowel.

\section{1. $\mathrm{U} \longrightarrow \mathrm{W} /------\mathrm{V}$}

The process can be illustrated in the following examples; 
Table 1: Showing glide formed from a stem

\begin{tabular}{|c|c|c|c|}
\hline $\begin{array}{c}\text { Morpheme } \\
\text { (denoting } \\
\text { doer) }\end{array}$ & Verb & $\begin{array}{c}\text { Derived } \\
\text { noun }\end{array}$ & Gloss \\
\hline $\mathrm{Mu}$ & Asha 'to light' & Mwashi & 'a person who lights' \\
\hline $\mathrm{Mu}$ & Alaga 'to kill' & Mwalagi & $\begin{array}{c}\text { 'a killer or a } \\
\text { murderer' }\end{array}$ \\
\hline $\mathrm{Mu}$ & Okola 'to save' & Mwokoli & 'a savior' \\
\hline $\mathrm{Mu}$ & Aviza 'to assist' & Mwavizi & 'an assistant' \\
\hline $\mathrm{Mu}$ & $\begin{array}{c}\text { Amboza 'to take } \\
\text { out' }\end{array}$ & Mwambozi & $\begin{array}{c}\text { 'a person who takes } \\
\text { another out' }\end{array}$ \\
\hline
\end{tabular}

Notice that in Kigiryama, to form a noun that denotes' the person who does,' the vowel in the /mu/ prefix changes to /w/ when the verb begins with a vowel sound.

\section{i. Glides formed on the root}

This type of glide formation occurs inside the root. The glide is formed morpheme -internally, either at morpheme medial position or morpheme final position. The same rule that accounts for glides formed on the stem, also accounts for glides formed on the root. Consider the following examples in Kigiryama.

Table 2: A table showing glides formed on the root

\begin{tabular}{|c|c|c|c|}
\hline $\begin{array}{c}\text { Morpheme } \\
\text { (denoting an } \\
\text { instrument/ part } \\
\text { of the body) }\end{array}$ & Root of the adjective & $\begin{array}{c}\text { Derived } \\
\text { word }\end{array}$ & Gloss \\
\hline $\mathrm{Lu}$ & $\begin{array}{c}\text { Alwa 'relating to } \\
\text { grind' }\end{array}$ & Lwalwa & $\begin{array}{c}\text { 'Grinding } \\
\text { stone' }\end{array}$ \\
\hline $\mathrm{Lu}$ & $\begin{array}{c}\text { Engu 'relating to } \\
\text { the pancreas' }\end{array}$ & Lwengu & 'Pancreas' \\
\hline $\mathrm{Lu}$ & $\begin{array}{c}\text { Ena 'relating to the } \\
\text { stomach' }\end{array}$ & Lwena & Flat stomach' \\
\hline $\mathrm{Lu}$ & $\begin{array}{c}\text { Anya 'relating to } \\
\text { teeth }\end{array}$ & Lwanya & $\begin{array}{c}\text { Gap between } \\
\text { teeth' }\end{array}$ \\
\hline $\mathrm{Lu}$ & $\begin{array}{c}\text { Ayo 'relating to the } \\
\text { foot' }\end{array}$ & Lwayo & 'foot' \\
\hline
\end{tabular}

From the above examples, we note that when the class prefix $/ \mathrm{lu} /$ is added to a root adjective beginning with a vowel, the $/ \mathrm{u} /$ in the prefix changes to a glide /w/.

Similarly the environment for glide formation results in the change of $/ \mathrm{u} /$ of the noun class prefix marker from $/ \mathrm{ku} /$ to $/ \mathrm{kw} /$. In the following Kigiryama examples the noun prefix is used as a prefix marker in locatives and pronouns.

Table 3: Showing the derivation of locative pronouns from adverbs of place

\begin{tabular}{|c|c|c|c|}
\hline Morpheme & Adverb root & Derived word & Gloss \\
\hline $\mathrm{Ku}$ & Akwe 'his/hers & Kwakwe & 'his/her place' \\
\hline $\mathrm{Ku}$ & Ao 'their' & Kwao & Their place' \\
\hline $\mathrm{Ku}$ & Enu 'your plural' & Kwenu & Your place (plural) \\
\hline $\mathrm{Ku}$ & $\begin{array}{c}\text { Ako 'your } \\
\text { singular' }\end{array}$ & Kwako & $\begin{array}{c}\text { Your place } \\
\text { (singular) }\end{array}$ \\
\hline $\mathrm{Ku}$ & Angu 'mine' & Kwangu & 'my place' \\
\hline $\mathrm{Ku}$ & Ehu 'our' & Kwehu & Our place' \\
\hline
\end{tabular}

Similarly, when the noun class prefix $/ \mathrm{mu} /$ is added to adjectival roots the same kind of change is observed. Notice the examples below.

\begin{tabular}{|ccc|c|c|}
\hline Morpheme & Adjective root & Derived word & Gloss \\
\hline $\mathrm{Mu}+$ & Iru 'black' & Mwiru & $\begin{array}{c}\text { 'Black hen or } \\
\text { person' }\end{array}$ \\
\hline $\mathrm{Mu}+$ & Aruhe 'white' & Mwaruhe & $\begin{array}{c}\text { White hen or } \\
\text { person' }\end{array}$ \\
\hline $\mathrm{Mu}+$ & Omu 'mean' & Mwomu & 'Mean person' \\
\hline $\mathrm{Mu}+\begin{array}{c}\text { Angwangu' } \\
\text { slim }\end{array}$ & Mwangwangu & 'slim person' \\
\hline $\mathrm{Mu}+$ & Oga 'fear' & Mwoga & 'fearful \\
\hline
\end{tabular}

Furthermore, the process of glide formation can also be illustrated with the Abstract noun prefix /u/ when attached to Adjectival roots especially with adjectives beginning with vowels. Notice the Kigiryama examples below.

\begin{tabular}{|c|c|c|c|c|c|}
\hline \multicolumn{2}{|c|}{ Mropheme } & \multicolumn{2}{|c|}{ Adjective root } & $\begin{array}{l}\text { Derived Abstract } \\
\text { noun }\end{array}$ & Gloss \\
\hline $\mathrm{U}$ & + & Iru & 'black' & Wiru & "Blackness' \\
\hline $\mathrm{U}$ & + & Aruhe & 'white & Waruhe & 'whiteness' \\
\hline $\mathrm{U}$ & + & Omu & "mean' & Womu & 'meanness' \\
\hline $\mathrm{U}$ & + & Oga & ' fear' & Woga & 'fearful' \\
\hline $\mathrm{U}$ & + & & & Wanu & 'stupidity’ \\
\hline $\mathrm{U}$ & + & $\begin{array}{l}\text { Itsi } \\
\text { foc }\end{array}$ & sh' & Witsi & Foolishness' \\
\hline
\end{tabular}

From all the examples above, it shows that glide formation occurs in Kigiryama where a high vowel either back or front precedes another vowel which is not identical with it i.e high back vowel /u/ will form a bilabial glide /w/ if followed by an unidentical vowel. The rule on the process of glide formation can be stated as follows:-

$$
\mathrm{U} \longrightarrow / \mathrm{W} /-------\mathrm{V}
$$

Similarly /j/ can also be formed by gliding in the case where the high front vowel /i/ glides to a /y/. this morph phonological change is shown with plural nouns in Kigiryama which are prefixed with $/ \mathrm{mi} /$ as illustrated in the data below:-

\begin{tabular}{|c|c|c|c|}
\hline Prefix & Base Form & Plural Form & Gloss \\
\hline $\mathrm{Mi}+$ & Anya 'space' & {$[$ Mjanya] } & 'Spaces/gaps' \\
\hline $\mathrm{Mi}+$ & Ongo 'back' & {$[$ Mjongo] } & 'Backs' \\
\hline $\mathrm{Mi}+$ & Aka 'mwaka' & {$[$ Mjaka $]$} & 'Years' \\
\hline $\mathrm{Mi}+$ & Ezi 'month' & {$[$ Mjezi] } & 'Months' \\
\hline $\mathrm{Mi}+$ & Oho 'fires' & {$[$ Mjoho] } & 'Fires' \\
\hline
\end{tabular}

Notice that what all the above examples illustrate is that the glide elements $\mathbf{w}$ and $\mathbf{y}$ are commonly inserted in morpheme boundaries with regard to the infixation of some morphemes. The same kind of phonetically motivated glide insertion is 
reported to Zayse (Hayward 1990). In particular, glide formation of w occurs where backness' neutralization occurs, and the same happens with the high front vowel /i/ in the prefix / $\mathrm{mi} /$ when it changes to $/ \mathrm{j} /$. In each case, the distribution of the two glide elements is conditioned by the phonetic nature of the preceding vowel in the prefix morpheme. If the vowel is a front vowel / $\mathrm{i} /$, the glide $\mathrm{y}$ is inserted, and if the vowel is a back vowel /u/, the glide $\mathrm{w}$ is inserted.

\subsubsection{Vowel Deletion}

Vowel deletion in Kigiryama occurs when one of the adjacent vowels is omitted in a particular phonological environment. It mostly occurs when two vowels of the different morphemes are in contact in the same word and the two vowels have the same phonological features then it is possible for one of the vowels to be deleted in order to avoid redundancy. See the examples below:-

\begin{tabular}{|c|c|c|c|}
\hline Prefix & Base Form & Derived Form & Gloss \\
\hline a.Wa + & Enye 'own' & [Wenye] & 'On its own' \\
\hline b. $\mathrm{Wa}+$ & Ao 'their' & [wao] & $\begin{array}{c}\text { 'Their } \\
\text { person/tree' }\end{array}$ \\
\hline c. $\mathrm{Ki}+$ & Ao 'their' & {$[$ chao] } & 'Their thing' \\
\hline d. $\mathrm{Ki}+$ & Angu 'mine' & [changu] & 'My thing' \\
\hline e. $\mathrm{Ki}+$ & Ehu 'our' & [chehu] & 'Our thing' \\
\hline f. $\mathrm{Ki}+$ & Akwe 'his/her' & [chakwe] & 'his/her thing \\
\hline
\end{tabular}

Notice in the data above, examples $\mathrm{c}, \mathrm{d}$, e, and $\mathrm{f}$ shows that the vowel in the morpheme ' $\mathrm{ki}$ ' is deleted once it has influenced the palatalization. The deletion of the vowel reduces redundancy and reduplication of phonetic features in the segments and in turn the features of the deleted segment are passed onto the changing segments.

\subsubsection{Vowel Height Assimilation.}

This kind of synchronic change is observed when two adjacent vowels harmonize and agree in their place of articulation and height, such that each one of them gives away its height features to be articulated at the same place of articulation in the mouth. This is a type of vowel coalescence where two vowels agree to be phonetically realized as one vowel. See the data illustrated below;

$\begin{array}{ll}\text { Morpheme } & \text { Root } \\ \text { 'our place' } & / \mathrm{Ha} / \text { 'place' }+ \text { ehu 'our' } \longrightarrow \text { hehu } \\ \text { your place' } & / \mathrm{Ha} / \text { 'place' }+ \text { enu 'your' } \longrightarrow \text { henu' } \\ \text { 'their place' } / \mathrm{Ha} / \text { 'place' }+ \text { ao 'their' } \longrightarrow \text { hao } & \\ \text { henye 'exact place } & \end{array}$

The data shows that in a sequence of /a/ and /e/, the two vowels merge into a phonetically realized / $\varepsilon /$. The two vowels seem to be in a kind of articulation compromise whereupon the two segments influence one another and agree to be articulated at a 'neutral' or more central position. /a/ is a low vowel while /e/ is a mid-high vowel. The compromise is such that the two vowels are phonetically realized as a mid-low vowel / $\varepsilon /$. This kind of influence is a reciprocal influence which results in vowel coalescence (Kumbatha 1998:68). This is why the sequence /e +e/ results into / $\varepsilon /$ which is an intermediary as far as vowel height is concerned.

\subsubsection{Vowel Insertion}

The process of vowel insertion in Kigiryama is most common in the Phonology of borrowed words originating mainly from English and Kiswahili. Whenever words are borrowed into Kigiryama, their syllable structure is altered to take the most preferred structure in this case the CVCV structure which is a closed syllable structure. Consider the following examples below;

\begin{tabular}{|c|c|c|c|}
\hline $\begin{array}{c}\text { Borrowed } \\
\text { Wigiryama }\end{array}$ & $\begin{array}{c}\text { Source } \\
\text { word }\end{array}$ & $\begin{array}{c}\text { Source } \\
\text { Language }\end{array}$ & Gloss \\
\hline Burangeti & blanket & English & blanket \\
\hline Dhakithari & doctor & English & doctor \\
\hline kondakita & conductor & english & conductor \\
\hline furiji & fridge & english & fridge \\
\hline sikuli & school & english & school \\
\hline Kilifi & cliff & English & cliff \\
\hline Mukahe & mkate & Kiswahili & Loaf of bread \\
\hline mufuko & mfuko & Kiswahili & A bag \\
\hline munazi & mnazi & kiswahili & A coconut tree \\
\hline muzungu & mzungu & Kiswahili & A European \\
\hline
\end{tabular}

The process occurs when a vowel is inserted where a consonant cluster occurs, also called Anaptyxis. Anaptyxis is the insertion of a vowel between two consonants to aid pronunciation. The rule governing Anaptyxis can be stated as follows:

$$
\mathrm{O} \longrightarrow[+ \text { syll }] / \mathrm{C}-\mathrm{C}
$$

The vowel /i/ is inserted in the middle of borrowed words like dhakithari.

In addition, vowel insertion can also occur in another way, in a process called paragogue. Paragogue is a process where a vowel is inserted at word final position. Most Bantu languages insert a segment at the end of a word and this process is governed by the following rule:-

$$
\mathrm{O} \longrightarrow[+ \text { Syll }]
$$

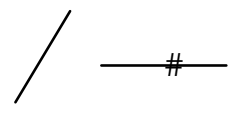

Notice the illustrated data below:- 


\begin{tabular}{|c|c|c|c|}
\hline $\begin{array}{c}\text { Borrowed } \\
\text { Kigiryama } \\
\text { word }\end{array}$ & Source word & Source language & Gloss \\
\hline Ripoti & report & English & report \\
\hline Kilasi & class & English & class \\
\hline Supu & soup & English & soup \\
\hline Petiroli & petrol & English & petrol \\
\hline Dizeli & diesel & English & diesel \\
\hline
\end{tabular}

In the examples above, the insetion of vowels is purely phonologically motivated. The vowel is inserted either medially or finally in the borrowed lexical item so as to create a phonologically accepted sound sequence in accordance with the Kigiryama phonology. Whenever vowels are inserted, the closed syllables are opened to make them conform to the preferred syllable structure.

\subsection{Phonological Processes involving Consonants}

In Kigiryama, most of the consonant changes in Kigiryama involve the noun prefix. The alterations occur when the morpheme for the noun prefix is added to another morpheme of a root word to form a stem.

\subsubsection{Palatalization}

Palatalization is a secondary articulation process where the primary articulation of a segment is changed so that it becomes a palatal. The sounds are said to be palatalized if the point of articulation moves towards the palatal region. The process is due to the influence of vowel height. In Kigiryama for palatalization to occur, there should be a sequence of two vowels except if the second vowel is a high vowel. It mainly occurs when a high vowel /i/ is followed by another vowel. Consider the following examples. 4

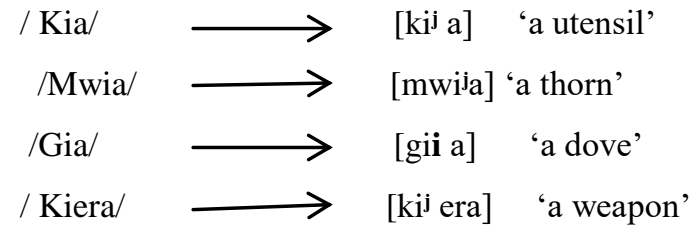

From the data illustrated above, the rule can be stated as follows:-

$$
\mathrm{C} \longrightarrow[+ \text { palatal }] /\left(\begin{array}{l}
\text { +high } \\
\text {-back }
\end{array}\right)\left(\begin{array}{c}
+ \text { high } \\
- \text { back }
\end{array}\right)
$$

\subsubsection{Labialization}

Labialization is an assimilatory process that has to do with lip rounding or lip protrusion. To any sound which is normally articulated with the lips in a neutral or spread position (Clark and Yallop, 1954:64). Labialization modifies the basic articulation by extending the length of the vocal tract and altering its cross section. According to Hyman (1988), labialization is a secondary consonant modification where in addition to the primary constriction, the lips are rounded and during pronunciation the consonant acquires $/ \mathrm{u} /$ or $/ \mathrm{w} /$ colouring. In Kigiryama it mainly occurs before rounded segments. It occurs whenever a consonant is preceded by a rounded segment. Below is a rule stating labialization.

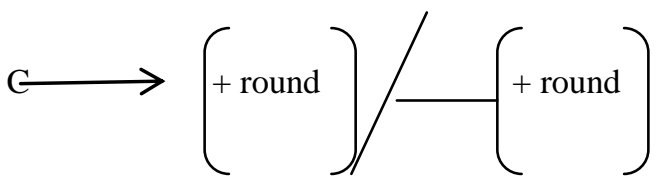

Consider the following Kigiryama examples:-

\section{Word Transcription Gloss}

Kwaha[ k' aha] $\longrightarrow$ 'armpit'

Kwera[ k' era] $\longrightarrow$ 'to climb'

Gwindi[g'indi ] $\longrightarrow$ 'a cassava tuber'

Lugwe $\left[\operatorname{lug}^{\mathrm{w}} \mathbf{e}\right] \longrightarrow$ 'a rope'

Kigwada[kigwada] $\longrightarrow$ 'cassava leaves dish'

Notice from the data given that consonants in Kigiryama are labialized when they precede a round vowel but not when they precede a non- round one. The process of labialization requires that a consonant precedes a round vowel for it to acquire [+round] features. The rule stipulated for the process is:-

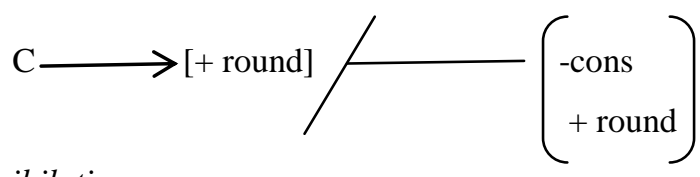

\subsubsection{Assibilation}

Assibilation is considered a two-step process. First the consonant undergoes palatalization then the palatalized form becomes a strident fricative. Assibilation in Kigiryama is mainly restricted to adjectives, pronouns and nouns where the consonant $/ \mathrm{k} /$ is followed by /ia/. Consider the following examples of pronouns in Kigiryama:-

$$
\begin{aligned}
& \begin{array}{llll}
\text { Step } 1 & \text { Step 2 } & \text { Word }
\end{array} \\
& / \mathrm{Ki}+\text { akwe } \longrightarrow \text { [kiakwe } \longrightarrow \text { [tfakwe] 'his/her (thing)' } \\
& / \mathrm{Ki}+\mathrm{ehu} \longrightarrow[\mathrm{kiehu} \longrightarrow[\mathrm{t} \text { ehu }] \text { 'our (thing)' } \\
& / \mathrm{Ki}+\mathrm{ao} / \longrightarrow[\mathrm{kiao}] \longrightarrow \quad\left[\mathrm{t} \int \mathrm{ao}\right] \text { 'their (thing)' } \\
& / \mathrm{Ki}+\text { angu/ } \longrightarrow[\text { kiangu } \longrightarrow[\mathrm{t} \text { angu }] \text { 'my (thing)' } \\
& / \mathrm{Ki}+\mathrm{enu} / \longrightarrow[\mathrm{kienu}] \longrightarrow\left[\mathrm{t} \int \mathrm{enu}\right] \text { your (thing) }
\end{aligned}
$$

In addition, palatalization in Kigiryama can be attested by the data on nouns illustrated below where velar consonants change to palatals;

$\begin{array}{cccc}\text { Step 1 Root } & \text { Step 2 } & \text { Transcription } & \text { Gloss } \\ / \mathrm{Ki}+\text { ape/ } & {[\mathrm{ki} \text { ape }]} & {[\mathrm{t} \text { ape }]} & \text { 'a beetle' } \\ / \mathrm{Ki}+\text { ala/ } & {[\mathrm{ki} \text { ala }]} & {[\mathrm{t} \text { ala }]} & \text { 'a finger' } \\ / \mathrm{Ki}+\text { akurya/ } & {[\text { kiakurya }]} & {[\mathrm{t} \text { akurya }]} & \text { 'food' }\end{array}$




$$
\begin{array}{cccc}
/ \mathrm{Ki}+\mathrm{ambo} / & {[\mathrm{ki} \text { ambo }]} & {[\mathrm{t} \text { ambo }]} & \text { 'bait' } \\
/ \mathrm{Ki}+\text { oga/ } & {[\mathrm{kioga}]} & {[\mathrm{t} \text { tambo]' a mushroom' }}
\end{array}
$$

Notice from the given data that the prefix $/ \mathrm{ki} /$ is seen to change when the root of the noun it is affixed to begins with a vowel. The 2 step process involved is that; first the velar consonant $/ \mathrm{k} /$ changes to $/ \mathrm{t} \mathrm{J} /$, a palatal sound and secondly the vowel /i/ is deleted.

\section{CONCLUSION \& RECOMMENDATIONS}

As a final section, this chapter summarizes and recapitulates the main findings of this project. It has been stated in the introductory chapter that the main goal of the present study is to provide a description of the phonology of Kigiryama. Towards that end, the study presents the most comprehensive account of the different aspects of the phonology of the language to date.

While examining the phonology of Kigiryama, different morphophonemic processes have been noted to occur in morpheme boundaries. The recurring morphophonemic processes are assimilation, coalescence, epenthesis, vowel raising and deletion. Epenthesis in Kigiryama involves both the insertion of a vowel to break an unwanted cluster of consonants and a glide insertion to avoid the coming together of vowels at morpheme.

While deep descriptive work is still lacking for many (most?) of the linguistic aspects in Kigiryama, my proposal for making progress at this point is to focus inward on the language and address these phonological phenomena from an historical and comparative perspective. While we have given a basic understanding of the issues in Kigiryama phonology, the field is still shrouded in mystery once we adopt a diachronic perspective. Questions such as the following have yet to be answered:

i. Where does tone come from in Kigiryama? ii. Where does ATR Vowel harmony come from in Kigiryama?

iii. How do labialization and palatalization arise in Kigiryama?

There are interesting and important discoveries still to be made in Kigiryama phonology and morphology. Second, when such phenomena are identified, it is important to pursue them in their genetic and geographic setting. If we are to understand how and why such systems arise, we will need first to establish the full range of possibilities, (Rialland 2007, Clements \& Rialland 2008) point out that there is much more waiting to be done in African Phonology.

\section{REFERENCES}

[1] Abdulmajid, M.A (2000) LuwangaMorphophonemics. Unpublished M.A Dissertation, University of Nairobi.

[2] Archangeli, Diana \& Terence Langendoen. (1997). Optimality Theory: An Overview. Wiley Blackwell

[3] Bauer, L. (2003). Introducing Linguistic Morphology.

[4] Gick, Bryan, Ian Wilson \& Donald Derrick. (2013). Articulatory Phonetics. Wiley Blackwell.

[5] Hyman L.M. (2008) Issues in African languages phonology. UC Berkeley Lab Annual Report.

[6] Johnson, Keith. (2011). Acoustic \& Auditory Phonetics. Blackwell.

[7] Kumbatha, G. M. (1998) KigiryamaMorphophonemicsin a Natural Generative Framework. Unpublished M.A Dessertation: University of Nairobi

[8] Ladefoged, Peter \& Ian Maddieson. (1996). The Sounds of the World's Languages. Blackwell.

[9] Ladefoged, Peter \& Keith Johnson. (2014). A Course in Phonetics. Peter Ladefoged\& Keith Johnson. Cengage Press. 5th edition or later

[10] Mweri, G. (1991) NP Movement. A Government and Binding approach. Unpublished M.A. Dissertation. University of Nairobi.

[11] Odden, David. (2005). Introducing Phonology. Cambridge University Press.

[12] Rialland, Annie. (2007). 'Question prosody: an African perspective. In Tomas Riad\& Carlos Gussenhoven (eds.), Tones and tunes: Studies in word and sentence prosody, vol. 1, 3562.Berlin: Mouton de Gruyter.

[13] Sirya, M. (1993) Verbal Morphology of Kigiryama. Nairobi: Bible Translation

Literacy. 